\title{
HABITAR, NARRAR E CONSTRUIR: A CASA MODERNA NOS RELATOS BIOGRÁFICOS DE SEUS MORADORES. ${ }^{1}$
}

\author{
TO INHABIT, TO NARRATE AND TO CONSTRUCT: THE MODERN \\ HOUSE IN THE BIOGRAPHICAL NARRATIVES OF ITS RESIDENTS. \\ HABITER, RACONTER, BATIR: LA MAISON MODERNE DANS LES \\ RECITS BIOGRAPHIQUES DE SES HABITANTS. \\ HABITAR, NARRAR Y CONSTRUIR: LA CASA MODERNA EN LOS \\ RELATOS BIOGRÁFICOS DE SUS HABITANTES.
}

Camila Gui Rosatti*

\begin{abstract}
RESUMO: Este artigo analisa relatos, a partir fontes diversas, de uma clientela que transformou em narrativa a experiência de habitar casas modernas. Desejosos de habitar um espaço atualizado às diretrizes estéticas de seu tempo, esse conjunto de clientes encomendou, entre o final dos anos 1940 e início dos anos 1960, a construção de suas residências a arquitetos que despontavam no cenário artístico paulistano. Permeado por tensões e ambiguidades, o relato da construção e vivência nessas moradias é uma fonte preciosa para acessar as expectativas em torno de novos padrões sociais e espaciais. Oscilando entre a apologia do vanguardismo arquitetônico e a reclamação dos infortúnios de se habitar uma casa fora dos padrões convencionais, essas narrativas e memórias permitem acessar o imaginário e as ambições de seus moradores, as motivações que os levaram a empreender esse projeto e as decepções quanto à sua realização. Também apresentam observações agudas da vida cotidiana, pelas quais é possível apontar marcadores sociais ligados a posição de classe, gênero e idade, assim como posições estéticas e políticas de um novo grupo social em busca de diferenciação.
\end{abstract}

Palavras-chave: casa moderna, memória, narrativa biográfica, habitantes.

\footnotetext{
${ }^{1}$ Este artigo recoloca novas questões teóricas e metodológicas ao material empírico coletado na minha pesquisa de doutorado em sociologia defendida sob o título Casas Burguesas, arquitetos modernos: condições sociais de produção da arquitetura moderna paulista. Durante o doutorado, recebi bolsa de pesquisa da Fundação de Amparo à Pesquisa do Estado de São Paulo (bolsa no país: FAPESP - processo 2012/14020-0 e bolsa de estágio de pesquisa no exterior: 2014/10276-6), a quem registro meus agradecimentos.

* Doutora em Sociologia; pós-doutoranda na Faculdade de Arquitetura e Urbanismo da Universidade de São Paulo (FAU-USP), São Paulo, SP, Brasil; E-mail: camila.rosatti@gmail.com
} 
ABSTRACT: This article intends to analyze the narratives of a clientele regarding their experience of inhabiting modern houses. Desiring to inhabit on spaces adapted to the new aesthetic guidelines of their time, these clients commanded, between the late 1940s and early 1960s, the construction of their residences to architects emerging in the artistic scene of São Paulo. Permeated by tensions and ambiguities, the chronicles describing the process of building and the daily life in these houses are a precious source for discussing the expectations arising from new social and spatial patterns. Between an apology of the architectural vanguardism and the misfortunes resulting from living in unconventional houses, these memories give access to the imaginary of these inhabitants and to the motivations that led them to undertake these projects and the disappointments. These stories also reveal poignant details about their daily lives, which reveal a set of social properties that can be linked to positions of class, gender, and age, as well as the differences in aesthetic and political positions of those engaged in this search for social the differentiation.

Keywords: modern house, memory, biographical narrative, inhabitants.

RÉSUMÉ: Cet article analyse les récits d'une clientèle qui a écrit sur l'expérience d'habiter des maisons modernes. Désireux de vivre dans un espace conçu selon les critères esthétiques de l'époque, ces clients ont commandé, entre la fin des années 1940 et le début des années 1960, leur résidence à des architectes novateurs de la scène artistique de São Paulo. Tissé de tensions et d'ambiguïtés, le récit de la construction et de la vie dans ces logements est une source précieuse pour accéder aux nouvelles transformations sociales et spatiales. Entre l'apologie de l'avant-garde architecturale et les plaintes suscitées par les malheurs d'habiter une maison ne correspondant pas aux schémas conventionnels, ces récits et mémoires permettent d'accéder à l'imaginaire, aux ambitions et aux motivations qui ont amenés ces commanditaires à entreprendre ce projet, ainsi qu'aux déceptions qu'il provoque. Ces récits offrent également de fines observations de la vie quotidienne, à partir desquelles il est possible d'identifier des marqueurs sociaux liés à la position de classe, de genre et d'âge, tout en révélant des positions esthétiques et politiques d'un nouveau groupe social en quête de différenciation. habitants.

Mots-clés: maison moderne, mémoire, récit biographique,

RESUMEN: En este articulo, a partir de diversas fuentes, se pretende analizar los relatos de una clientela que transformó en narrativa su experiencia de habitar las casas modernas. Deseosos de 
habitar un espacio adecuado a las nuevas directrices estéticas de su tiempo, estos clientes encomendaron entre finales de los años 1940 y principios de los años 1960, la construcción de sus residencias a arquitectos que emergían en el escenario artístico paulistano. A pesar de que los relatos sobre la construcción y vivencia en estos nuevos hogares, dichos documentos son sin lugar a dudas una fuente muy valiosa para acceder a las expectativas en torno a nuevos patrones sociales y espaciales. Entre la apología del vanguardismo arquitectónico y las quejas ocasionadas por los infortunios de habitar una casa al margen de patrones convencionales, esas narrativas y memorias permiten acceder al imaginario, a las ambiciones de sus habitantes y a las motivaciones que los llevaron a emprender ese proyecto y las decepciones. Asimismo, dichos relatos presentan observaciones agudas sobre la vida cotidiana, gracias a las cuales es posible observar ciertos marcadores sociales ligados a la posición de clase, género y edad, así como las diferentes posturas estéticas y políticas de un nuevo grupo social en busca de la diferenciación.

Palavras claves: casa moderna, memoria, narrativa biográfica, habitantes.

"Uma casa tem muita vez as suas relíquias, lembranças de um dia ou de outro, da tristeza que passou, da felicidade que se perdeu. Supõe que o dono pense em as arejar e expor para teu e meu desenfado. Nem todas serão interessantes, não raras serão aborrecidas, mas, se o dono tiver cuidado, pode extrair uma dúzia delas que mereçam sair cá fora."

Machado de Assis, Reliquias da Casa Velha.

\section{INTRODUÇÃO}

Memórias são mensagens densas de sentido e, tal como relíquias, conservam a dimensão material e simbólica, real e imaginária de um indivíduo; revelam escolhas, comportamentos e representações expressivas das diversas inscrições sociais do narrador. O que proponho neste artigo é repertoriar e analisar um conjunto de narrativas de estatuto variado, o qual possui a particularidade de se referir à casa moderna brasileira e, mais ainda, vale realçar, a partir do ponto de vista de seus moradores. Esses testemunhos, extraídos de fontes diversas, apresentam registro muito heterogêneo quanto à forma da narrativa e às condições de produção: são trechos de entrevistas, 
biografias e autobiografias que foram publicados como livro, ensaio em revista e também coletados em entrevista como fonte primária.

Percorrendo a diversidade dos relatos, chama a atenção o empenho com que esses moradores optaram por escrever algumas linhas íntimas, contar alguma anedota familiar ou propor descrição e análise fazendo alusão à casa que sonharam morar e estiveram em condições de construir. Para entender os inevitáveis ajustes entre o imaginado, o vivido e o narrado, algumas questões se colocam. Como analisar esses relatos, que misturam memórias, testemunhos e ensaio de interpretação? De que maneira o discurso sobre a casa, investimento indubitável de publicização de uma narrativa, e a casa propriamente dita, investimento profundo na materialização de um projeto individual e familiar, podem constituir um material para análise de experiências sociais? Quem é o proprietário, sob qual registro a casa é narrada e em que momento ela se situa na vida do morador?

Estas questões ganham especial interesse quando se tem em conta a especificidade formal e estética desses projetos de arquitetura concebidos por profissionais que buscaram colocar em prática princípios do racionalismo arquitetônico. São casas modernas, no sentido artístico do termo, que estão ligadas a um projeto de renovação das linguagens e das convenções arquitetônicas. Elas estão carregadas de sentido, tanto por parte dos produtores, os arquitetos, que desenvolveram narrativa intelectual e estética sobre o espaço arquitetônico, quanto por parte dos consumidores, os encomendantes e moradores, que as escolheram como espaço para reprodução social e biológica de suas famílias, citando aqui os termos que Bourdieu usa para analisar a questão da transmissão e da constituição do patrimônio material e simbólico em torno da casa (Bourdieu, 1990, 2006).

A utilização de relatos e memórias para adentrar no universo da casa é uma aposta metodológica que apresenta dupla motivação, sociológica e arquitetônica. O entendimento é que essas narrativas possibilitam, de um lado, acessar as lógicas sociais em que se inscrevem os moradores e, de outro, dar carne e osso à história da arquitetura, canonicamente narrada a partir da materialidade do edifício. 
Do ponto de vista sociológico, a narrativa desses agentes nos permite pensar a casa a partir da memória, do sentido que os moradores constroem acerca da experiência vivida e, assim, levantar uma série de questões sobre marcadores sociais, filtrados pelos limites de evocação do relato. $\mathrm{O}$ discurso biográfico é um gênero narrativo que traz diversos eventos e situações cotidianas em múltiplos domínios e momentos, organizados na estrutura do percurso de vida. Questões de gênero, geração, idade, gosto, classe, profissão, práticas culturais e engajamento político estão aí presentes. Essas inscrições sociais atravessam as narrativas recolhidas de diferentes modos, o que torna imperioso examiná-las não apenas a partir de uma dessas categorias isoladas. Esses marcadores sociais se constituem relacionalmente; dito em outros termos, as condições de pertencimento social se ativam e se modificam umas em relação às outras.

Em se tratando da memória ligada à casa, esse ponto é particularmente interessante quando se considera que o espaço doméstico está marcado por pressuposições, também socialmente construídas - a mais evidente, a de que seria "naturalmente" lugar do feminino1. Como mostram diversos trabalhos, o tema da casa traz, inevitavelmente, questões ligadas a domesticidade e gênero (Bourdieu, 1999; Carvalho, 2008; Lira et al., 2017). É preciso levar em conta que o espaço da casa foi visto historicamente como lugar de práticas tipicamente femininas e que o papel da mulher estaria restrito à ordem privada, ao se sustentar a ideia que a mulher estaria voltada "para dentro", para o privado, e o homem "voltado para fora", para o público. O desafio, então, é evitar tomar o gênero como categoria essencializada, atentando-se que tal marcador social se construiu historicamente em experiências sociais complexas, nas quais participam outros marcadores sociais também significativos, como os ligados à classe, geração, estilos de vida, posicionamento político (Scott, 1990; Pontes, 2008, 2016).

\footnotetext{
1 Essas pressuposições incidem inclusive sobre a validação do objeto de pesquisa, como bem indicou Gilberto Freyre, em 1936, na introdução de Sobrados e Mucambos, ao falar sobre a recepção de Casa-Grande \& Senzala. O autor nomeia a oposição entre "varonilidade sociológica" e a "sociologia apenas do interior", apontando que, para uma parte dos seus críticos, ele havia feito uma sociologia menor, ao suporem que o tema da casa seria assunto irrelevante, pois se trataria da ordem do privado, caseiro, cotidiano, íntimo, "docemente inofensivo" por estar sobremaneira vinculado às "preocupações femininas" (Freyre, 2004, pp. 100-101).
} 
Portanto, é nesse sentido que os relatos biográficos são particularmente interessantes: eles permitem reconstituir constrangimentos experimentados pelos narradores a partir de diversos feixes sociais, uma vez que, na tentativa de dar coerência a seus percursos de vida, eles trazem acomodações subjetivas de fenômenos culturais mais amplos. Nos termos da antropologia da habitação moderna, tal como definiu Marion Segaud, as transformações do habitat evidenciam "como condensado de uma totalidade (...) múltiplos registros que, ao se hierarquizarem, confrontam o cósmico e o cotidiano, o espaço e o tempo, o feminino e o masculino, a natureza e a cultura, sempre se inscrevendo na habitação" (Segaud, 2010, p. 212).

Do ponto de vista da história da arquitetura, o interesse nos testemunhos é que eles são fontes que trazem a perspectiva "de dentro", isto é, oferecem informações de um morador singular que habita o espaço. Quando o material biográfico registra a densidade da experiência de habitar, é possível abordar a casa não exclusivamente como espaço construído, mas sobretudo como espaço vivido, isto é, como construção eminentemente social (Certeau, 2001). Isso se dá a ver nos relatos dos moradores coletados, nos quais a casa se apresenta com múltiplas dimensões sociais e, portanto, de forma diferente da comumente tratada pelas abordagens centradas nos produtores, para as quais a atuação do arquiteto está na ordem da "genialidade", ou pelas abordagens tecnicistas e formalistas, que dão primazia à materialidade arquitetônica a partir das questões construtivas e estéticas. Na história da arquitetura canônica, as visões que deram centralidade ao autor e à obra acabaram por confinar o habitat em uma leitura predominantemente marcada pelo purismo plástico.

Por outra via, a narrativa biográfica torna possível colocar em causa a imagem autoral e estetizante da arquitetura moderna - por vezes mostrada como uma estrutura rígida e desabitada -, fazendo face ao mito funcionalista e estandartizante da casa como uma “máquina de morar", lema da arquitetura moderna postulado pelo arquiteto franco-suíço Le Corbusier, considerado um dos principais fundadores do racionalismo arquitetônico. Em vez da moradia que se supunha universal, generalizável e esvaziada dos traços da expe- 
riência, temos relatos individuais localizados no tempo e no espaço que apresentam o imaginário cultural e expõem as condições sociais de consumo do morar moderno.

Seguindo trabalhos clássicos da sociologia, a abordagem aqui proposta assenta-se no pressuposto de que as casas expressam maneiras de pensar, agir e estar no espaço e estão diretamente ligadas às experiências e expectativas sociais de determinados grupos que ocupam posições específicas no espaço social. O entrelaçamento entre as estruturas de habitação e as estruturas sociais foi exemplarmente trabalhado por Norbert Elias, ao tratar dos padrões de distinção e prestígio na sociedade de corte francesa no período do Antigo Regime (Elias, 2001). Nessa sociedade altamente hierarquizada, o domicílio do rei é mais que a unidade familiar, ele é toda a corte, em seu sentido amplo, pois é o espaço onde o rei exerce seu poder e constitui o Estado.

Antes de Elias, Gilberto Freyre já havia apresentado, de modo abrangente e primoroso, interpretação sobre a estrutura social brasileira a partir da casa. Em sua obra, as casas dos grupos dominantes (casa-grande e sobrados) e a casa dos grupos dominados (senzala e mucambos) são tomadas como pares estruturais dicotômicos organizadores da experiência social brasileira desde o antigo sistema colonial até nas novas relações dadas pelo desenvolvimento urbano que se inicia no final do século XIX (Freyre, 2004, 2006). A estrutura habitacional é o centro do interesse de Freyre pois, como ele afirma, para além dos grandes temas políticos clássicos, a casa é o locus principal de antagonismos e acomodações que caracterizam os processos de diferenciação social no Brasil. O autor mostra que a casa é o espaço onde se organiza a vida cotidiana, que, longe de ser ordinária ou banal, é, ao contrário, instância constituidora da trama social que perpassa todos os grupos.

Pierre Bourdieu também apresenta importantes contribuições para pensar a moradia como materialização de relações sociais. No estudo etnográfico sobre os kabyles, um dos povos berberes do norte da Argélia, a casa materializa as cosmologias do grupo. As oposições entre alto e baixo, dia e noite, seco e úmido, íntimo e público 
estão presentes na casa, pois elas também são estruturantes da lógica social dos kabyles (Bourdieu, 1999). Já em Estruturas Sociais da Economia, estudo sobre os significados sociais e econômicos da aquisição da casa própria na sociedade francesa dos anos 1980, a moradia é vista em seu papel estratégico para reprodução da familiar. Em sua análise relacional, a casa é vista como produto visível e facilmente notável da condição social de seu proprietário, daí seu caráter altamente distintivo: ela "exprime ou trai, de forma mais decisiva que outros, o ser social de seus proprietários, os seus 'meios', como se costuma dizer, mas também os seus gostos, o sistema de classificação que ele envolve em seus atos de apropriação" (Bourdieu, 2006, p. 37).

Esses aportes teóricos sobre a casa contribuíram para definir a leitura eminentemente sociológica aqui utilizada. Com ela, entre o social e o individual, entre a representação pública e a constituição do espaço privado, entre o masculino e feminino, entre as escolhas por estilos moderno ou neocolonial, procura-se mostrar confrontos, resistências e coexistências que se constituem no habitat. Na apropriação e reelaboração dos modelos de moradias modernas, os habitantes demarcam seus estilos de vida, entendendo também o caráter distintivo do acesso a esse tipo de bem tão exclusivo e tão identitário que é a propriedade privada da moradia.

Isso nos leva a destacar a morfologia social do grupo em questão, que surgiu com diversificação dos padrões sociais e culturais na São Paulo logo a partir dos anos 1940. São novas frações de classe em gradativa ascensão social, que, em termos gerais, podem ser identificadas como pertencentes a camadas médias e altas urbanas, bastante escolarizadas, profissionalizadas e culturalmente privilegiadas. As condições de apropriação das novas configurações espaciais, tanto arquitetônicas quanto urbanas, são expressivas dessa condição privilegiada.

As casas modernas que lhes serviram de abrigo estão localizadas em bairros nobres e exclusivos, cujo modelo de urbanização seguiu os padrões de loteamento ingleses chamado "garden city" (Howard, 1996; Wolff, 2001). A exclusividade desses bairros deve-se 
à regra estrita de ocupação e construção que define uso unicamente residencial, com construção de casas unifamiliares isoladas no lote e com exigência de recuos laterais e frontais. A excepcionalidade do espaço urbano é notável pelo traçado não ortogonal das ruas, todas elas sinuosas e bastante arborizadas, e pela presença de praças e jardins, concepção que repercute o modelo pitoresco de contemplação e fruição da paisagem no projeto do espaço urbano. Essas qualidades foram grande chamariz para atrair grupos sociais com excelentes condições financeiras, conformando espaços distintivos e seletivos que implicaram em homogeneidade social.

As narrativas reunidas (e as casas a que se referem) estão atravessadas por representações e interesses dos moradores que as encomendaram, que fazem parte de uma fração intelectual e politizada em ascensão na capital paulista nos meados dos anos 1950, e esses relatos constituem material precioso para acessar as tensões e ambiguidades do grupo. A proposta do artigo é, assim, explorar sistematicamente esse material tendo em vista a possibilidade de oferecer uma visão interna e densa sobre a relação dos indivíduos com esses espaços, atentando-se para os requisitos metodológicos que o discurso biográfico comporta.

\section{NARRATIVA E CONSTRUÇÃO SOCIAL: ALGUNS RECUR- SOS ANALÍTICOS E METODOLÓGICOS}

A variedade de relatos coletados incita a mobilizar referências bibliográficas específicas sobre o uso de biografias nas ciências sociais. Trabalhos historiográficos, sociológicos, antropológicos têm em diversas direções apontado o interesse no uso de dados individuais e subjetivos, como fonte essencial de conhecimento sobre múltiplas temporalidades, processos de socialização e construções de identidade (Bourdieu, 1986; Passeron, 1990; Bessin, 2009; Dubar \& Nicourd, 2017). Para os pesquisadores, um dos fascínios do documento biográfico é a expressividade que o "caso" singular traz junto ao poder de sugestão da narrativa, pois a sucessão de eventos, escolhas pessoais e constrições institucionais possibilita pensar sobre os 
efeitos da realidade social sobre um destino humano, o que supõe uma ligação entre o processo de individuação e a estrutura social.

De modo geral, esses trabalhos apresentam reflexões valiosas sob o ponto de vista analítico e epistemológico, sobretudo apontando que o material biográfico e memorialista não pode ser tomado como fonte precisa, neutra e indefectível. Silêncios, ausências, esquecimentos, interditos, reinterpretações, ficcionalizações se fazem presentes e isso pressupõe instrumentos metodológicos para tentar dar conta daquilo que é evidente, mas corre o risco de ser negligenciado: a dimensão inerente de construção mental, literária e cultural que a narrativa biográfica contém em si (Rosset, 2010).

O perigo de adesão ao conteúdo ficcional da narrativa e o risco de incorrer em uma reconstrução teleológica da vida de um indivíduo foram alertados por Pierre Bourdieu em seu conhecido artigo sobre o uso de biografias, "A ilusão biográfica”, no qual o autor apresenta questionamentos metodológicos em relação ao uso desse material (Bourdieu, 1986). No entanto, não se trata de uma crítica que invalida sua utilização. Para controlar as fontes e não sucumbir à narrativa que ambiciona sempre buscar coerência e direção única, o sociólogo defende a necessidade de reconstrução sistemática das propriedades sociais dos indivíduos, bem como dos espaços sociais que eles participam. Ademais, para o sociólogo Howard Becker, o discurso em primeira pessoa é imperativamente ligado a uma versão da realidade social, uma vez que o narrador "escolhe os fatos de maneira a nos apresentar a imagem que ele gostaria que tivéssemos" (Becker, 1986, p. 105). Na tentativa de dar conta desses feixes de histórias, o autor oferece a ideia de "mosaico científico", como recurso analítico para reunir peças de um quadro mais amplo e observá-las em suas relações recíprocas.

Aqui, portanto, o desafio é caracterizar uma experiência particular, adensada com dados do percurso de vida do indivíduo, sem, no entanto, essencializar o discurso individual, atribuindo caráter de excepcionalidade ou unicidade. O antídoto, como indicam os trabalhos metodológicos, é comparar experiências similares, de modo a extrair a dimensão coletiva das práticas. A imagem do mosaico é inspiradora e aqui será particularmente mobilizada para pensar a 
coleção de relatos sobre a moradia moderna uma em relação à outra e, assim, a partir da análise das diversas modalidades de registros, enriquecer a compreensão sobre as formas de representação e uso do espaço arquitetônico doméstico moderno. Esse procedimento analítico permite capturar diferentes formas de viver as injunções entre espaço privado, projeto individual e construção de representações coletivas. Com isso, a partir das várias "peças", espera-se oferecer uma leitura mais dinâmica e complexificada sobre os compromissos e as intenções que levaram esses moradores a se encantar por modos diferenciados de morar moderno.

Tratados em conjunto e buscando diferenciá-los em seu contexto de produção, esses relatos oferecem pistas expressivas sobre valores, crenças e constrições que permitem aflorar, a partir da subjetividade, uma experiência social e histórica definida. É, portanto, a dupla dimensão coletiva e individual, concreta e subjetiva da biografia que pode ser particularmente útil para dar carne e osso a história da arquitetura moderna e fornecer um leque amplo de questões sobre as relações entre arquitetura, os modos de morar e a reprodução da família, bem como, no plano das demandas simbólicas, as relações entre espaço físico, escolha estética e estilos de vida.

\section{PEÇAS DO MATERIAL EMPÍRICO}

A base empírica deste trabalho se baseia em sete relatos biográficos que, embora não tenham valor amostral, permitem ser examinados como casos exemplares ou, em outros termos, casos sínteses, pois apresentam um espectro largo de marcadores sociais e temporais. O quadro abaixo procura organizar informações em relação ao ano do projeto da casa, local em que foi construída, propriedades sociais do cliente que fez a encomenda, nome do arquiteto, tipo de relato encontrado, autor do relato e posição em relação à família moradora na residência. A explicitação desses dados é fundamental para situar o lugar social do narrador, bem como o momento da encomenda e o contexto da escrita, demarcando o ponto de vista e as propriedades sociais de quem enunciou. 


\begin{tabular}{|c|c|c|c|c|c|c|c|}
\hline $\begin{array}{c}\text { Ano do } \\
\text { projeto casa/ } \\
\text { local - bairro } \\
\text { cidade } \\
\end{array}$ & $\begin{array}{l}\text { Encomen- } \\
\text { dante da } \\
\text { casa } \\
\text { (quem é } \\
\text { nomeado) }\end{array}$ & \begin{tabular}{|l|} 
Propriedades \\
sociais do en- \\
comendante
\end{tabular} & \begin{tabular}{|c|} 
Autor do \\
relato/ \\
posiçãa em \\
relação à \\
família
\end{tabular} & $\begin{array}{l}\text { Tipo de } \\
\text { relato }\end{array}$ & \begin{tabular}{|c|} 
Descrição \\
sucinta \\
(como a casa \\
é referida no \\
relato)
\end{tabular} & \begin{tabular}{|c|} 
Data \\
do \\
relato
\end{tabular} & $\begin{array}{l}\text { Arqui- } \\
\text { teto do } \\
\text { projeto }\end{array}$ \\
\hline $\begin{array}{l}\mathbf{1 9 4 8} \\
\text { Jardim Europa } \\
\text { São Paulo }\end{array}$ & $\begin{array}{l}\text { Febus Giko- } \\
\text { vate }\end{array}$ & $\begin{array}{l}\text { Médico, ju- } \\
\text { deu, militante } \\
\text { trotskista, } \\
\text { professor } \\
\text { Santa Casa }\end{array}$ & $\begin{array}{l}\text { Flávio Giko- } \\
\text { vate, filho }\end{array}$ & \begin{tabular}{|l|} 
Depoimen- \\
to escrito a \\
terceiros
\end{tabular} & $\begin{array}{l}\text { "Mais } \\
\text { bonita do que } \\
\text { eficiente e } \\
\text { funcional" }\end{array}$ & 2009 & $\begin{array}{l}\text { Vilanova } \\
\text { Artigas }\end{array}$ \\
\hline $\begin{array}{l}1949 \\
\text { Sumaré } \\
\text { São Paulo }\end{array}$ & $\begin{array}{l}\text { Oduvaldo } \\
\text { Vianna }\end{array}$ & $\begin{array}{l}\text { Escritor, } \\
\text { dramaturgo, } \\
\text { militante } \\
\text { comunista }\end{array}$ & $\begin{array}{l}\text { Deocélia } \\
\text { Vianna, } \\
\text { esposa }\end{array}$ & $\begin{array}{l}\text { Autobio- } \\
\text { grafia sobre } \\
\text { a família }\end{array}$ & $\begin{array}{l}\text { "A proprie- } \\
\text { dade é um } \\
\text { roubo"; } \\
\text { "A casa mais } \\
\text { maluca que já } \\
\text { vi em minha } \\
\text { vida". }\end{array}$ & 1984 & $\begin{array}{l}\text { Vilanova } \\
\text { Artigas }\end{array}$ \\
\hline $\begin{array}{l}1949 \\
\text { Pacaembu } \\
\text { São Paulo }\end{array}$ & $\begin{array}{l}\text { Juljan } \\
\text { Czapski }\end{array}$ & Médico & $\begin{array}{l}\text { Silvia Czap- } \\
\text { ski, filha }\end{array}$ & \begin{tabular}{|l|} 
Biografia \\
sobre o pai \\
publicada \\
como livro
\end{tabular} & $\begin{array}{l}\text { "Vida nova, } \\
\text { casa nova"; } \\
\text { "Mais um } \\
\text { preço da } \\
\text { arquitetura, } \\
\text { que colocava } \\
\text { beleza acima } \\
\text { da praticida- } \\
\text { de"" }\end{array}$ & 2011 & $\begin{array}{l}\text { Vilanova } \\
\text { Artigas }\end{array}$ \\
\hline $\begin{array}{l}1950 \\
\text { Pinheiros } \\
\text { São Paulo }\end{array}$ & $\begin{array}{l}\text { David Ro- } \\
\text { semberg }\end{array}$ & $\begin{array}{l}\text { Médico, judeu, } \\
\text { simpatizante } \\
\text { comunista, } \\
\text { professor } \\
\text { universitário }\end{array}$ & $\begin{array}{l}\text { Lia Rosem- } \\
\text { berg, filha }\end{array}$ & $\begin{array}{l}\text { Entrevista } \\
\text { à autora }\end{array}$ & $\begin{array}{l}\text { Casa dos } \\
\text { namoros de } \\
\text { infância }\end{array}$ & 2013 & $\begin{array}{l}\text { Vilanova } \\
\text { Artigas }\end{array}$ \\
\hline $\begin{array}{l}\mathbf{1 9 6 1} \\
\text { Ilhabela }\end{array}$ & $\begin{array}{l}\text { Heloísa Al- } \\
\text { ves de Lima } \\
\text { Motta }\end{array}$ & $\begin{array}{l}\text { Trabalho } \\
\text { voluntariado, } \\
\text { rentista, elite } \\
\text { aristocrática }\end{array}$ & \begin{tabular}{|l|} 
Heloísa \\
Alves de \\
Lima Motta, \\
encomen- \\
dante
\end{tabular} & \begin{tabular}{|l|} 
Autobio- \\
grafia \\
publicada \\
como livro \\
- Uma \\
menina \\
Paulista \\
\end{tabular} & $\begin{array}{l}\text { "Cópia da } \\
\text { Casa do Ban- } \\
\text { deirante" }\end{array}$ & 1992 & $\begin{array}{l}\text { Paulo } \\
\text { Mendes } \\
\text { da Rocha }\end{array}$ \\
\hline $\begin{array}{l}1961 \\
\text { City Butantã } \\
\text { São Paulo }\end{array}$ & $\begin{array}{l}\text { Boris } \\
\text { Fausto }\end{array}$ & $\begin{array}{l}\text { Advogado, } \\
\text { historiador, } \\
\text { judeu } \\
\text { USP }\end{array}$ & $\begin{array}{l}\text { Boris } \\
\text { Fausto, } \\
\text { encomen- } \\
\text { dante }\end{array}$ & \begin{tabular}{|l|} 
Autobio- \\
grafia \\
publicada \\
como livro \\
- Memó- \\
rias de um \\
historiador \\
de domingo \\
\end{tabular} & $\begin{array}{l}\text { "foi visível } \\
\text { seu desa- } \\
\text { grado [do } \\
\text { arquiteto] } \\
\text { ao constatar } \\
\text { alterações na } \\
\text { casa" }\end{array}$ & 2010 & $\begin{array}{l}\text { Sérgio } \\
\text { Ferro }\end{array}$ \\
\hline $\begin{array}{l}1968 \\
\text { City } \\
\text { Butantã } \\
\text { São Paulo }\end{array}$ & \begin{tabular}{|l} 
Juarez \\
Brandão
\end{tabular} & $\begin{array}{l}\text { Sociólogo, } \\
\text { professor } \\
\text { universitário } \\
\text { USP }\end{array}$ & $\begin{array}{l}\text { Juarez } \\
\text { Brandão, } \\
\text { encomen- } \\
\text { dante }\end{array}$ & \begin{tabular}{|l|} 
Testemu- \\
nho, ensaio \\
analitico, \\
publicado \\
em revista \\
-"Con- \\
sumo da \\
arquitetura \\
moderna" \\
\end{tabular} & $\begin{array}{l}\text { "A casa não } \\
\text { foi feita } \\
\text { para 'ter' } \\
\text { empregadas"; } \\
\text { "Concessão } \\
\text { irrecusável ao } \\
\text { presente" }\end{array}$ & 1973 & $\begin{array}{l}\text { Rodrigo } \\
\text { Lefèvre } \\
\text { e Flávio } \\
\text { Império }\end{array}$ \\
\hline
\end{tabular}


O quadro permite tecer considerações comparativas em relação a cinco pontos, a saber: diversidade da clientela, distribuição urbana das residências, variedade da narrativa (contexto temporal e posição do enunciador), processo de designação das residências e grupo geracional dos arquitetos.

Em primeiro lugar, em relação à diversidade da clientela, como se pode observar pelo quadro, essas casas foram projetadas entre o final dos anos 1940 e 1960, largo período de 20 anos que representa o recrutamento de dois grupos geracionais um pouco diferenciados em termos de origem social e profissionalização. No final da década de 1940 e durante a de 1950, destaco na clientela de Vilanova Artigas (1915-1985) a presença de profissionais liberais, médicos e escritores, todos ligados à militância de esquerda com filiação ou simpatizantes do Partido Comunista. Os sobrenomes indicam a questão imigratória para qual é possível sinalizar que se trata de primeira ou segunda geração de estrangeiros que se fixaram na capital paulistana, em busca de novas oportunidades de vida ou em fuga de condições da perseguição religiosa nazista contra judeus. Já nos anos 1960, a clientela de Flávio Império (1935-1985), Rodrigo Lefèvre (1938-1984) e Sérgio Ferro (1938-), reconhecidos na história da arquitetura por formar o grupo "Arquitetura Nova", orientou-se a um novo grupo social, constituído principalmente por intelectuais ligados à universidade. As casas de Juarez Brandão e Boris Fausto, ambos intelectuais cuja carreira profissional esteve ligada à Universidade de São Paulo, são significativas dessa condição.

Em segundo lugar, vale destacar que essas diferenças se expressam em termos de distribuição geográfica: enquanto as casas de Artigas estão localizadas em bairros residenciais dentro dos limites do rio Pinheiros, em loteamentos construídos no início do século XX, como Pacaembu e Sumaré, as duas casas dos anos 1960 estão situadas no City Butantã, bairro cuja ocupação residencial foi impulsionada pela instalação do campus universitário da Universidade de São Paulo e a consequente transferência das faculdades e laboratórios de pesquisa, antes concentrados no centro histórico e econômico. Nesse período, o novo eixo de expansão urbana seguiu o 
vetor oeste, alcançou a outra margem do rio Pinheiros e consolidou novos loteamentos residenciais de elite, com a adoção do padrão de urbanização inspirado no modelo cidade-jardim, empreendidos pela mesma empresa urbanizadora, a Companhia City.

Ainda sobre a questão geográfica, inclui-se na coleção dos relatos a casa projetada por Paulo Mendes da Rocha (1928-) em Ilhabela, litoral norte paulista, conhecido espaço de vilegiatura da elite paulistana. Esse caso traz para o conjunto um investimento recorrente dessa clientela, a posse de casas secundárias com intuito de prática cultural e de lazer. A casa de fim de semana e de veraneio, modalidade específica de usufruto do tempo livre que envolve grande demanda de capital econômico, é expressão distintiva da posição privilegiada econômica, social e simbólica de seus proprietários. Sua finalidade está ajustada a demandas simbólicas específicas de convívio de classe, uma vez que tem a função de receber familiares e amigos em momentos de lazer e festa ou emprestar a pessoas próximas do círculo social, servindo, assim, de espaço de reprodução dos capitais sociais de seus proprietários. Em relação ao estilo arquitetônico e ao programa funcional, as casas secundárias na praia, na montanha ou no campo são geralmente vistas como espaços de descanso e divertimento mais despojados, menos exigentes e pretensiosos em relação aos padrões de decoração e às necessidades de ostentação social. Nessas casas, os encomendantes permitem ousar soluções diferentes das casas oficiais na cidade. Ainda que a contratação de um arquiteto moderno se mostre como aposta vanguardista, no caso em questão, como se verá, a escolha esteve condicionada às representações e valores tradicionais de uma antiga descendente da aristocracia paulistana.

O terceiro ponto geral a registrar é a temporalidade, o contexto de enunciação e a variedade dos enunciadores. Como se procurou indicar no quadro, essas narrativas foram produzidas em momentos distintos, por moradores que, através da escrita rememorativa ou do relato testemunhal, procuraram narrar, analisar, refletir, indagar sua própria trajetória ou a trajetória de seus moradores. Tem-se, de partida, a questão sobre o tipo de registro, quem narra e sob qual ponto de vista, bem como sobre a distância no tempo e a possibilidade da lembrança e da 
construção da memória. A diversidade de temporalidade dos relatos coletados permitiu constituir um painel amplo de pontos de vista, seja no tempo, seja na condição familiar e social do morador, cada qual submetidos a lógicas diferenciadas: o adulto que traz à memória a experiência da infância; a senhora viúva de extração aristocrática que se vangloria de sua condição de mulher ativa e independente; a filha que reconstitui a trajetória de ascensão do pai, com a construção, a curta permanência saudosa e a mudança da casa; a esposa que reconstitui a biografia da família e os malogros que impediram de morar de fato na residência recém-construída; o intelectual que avalia sua prática individual e aposta na mudança coletiva; e o historiador que analisa os projetos da juventude, desapontado com as ilusões políticas de então. $\mathrm{O}$ relato sobre a casa possui, portanto, tonalidades narrativas que estão submetidas a variáveis temporais, aos múltiplos pertencimentos sociais dos moradores e à condição de quem narra.

O quarto ponto a destacar é em relação ao processo social de designação das residências, cuja lógica é reveladora da construção social de hierarquias com dimensão de gênero. As "casas de arquitetos" são, na maioria das vezes, intituladas pelo nome de seu encomendante, mesmo quando a casa de uma família é o nome do marido, reproduzindo a condição de chefe-da-família, que passa a ser o título identificador da residência. Essa é forma que se convencionou utilizar no carimbo de identificação dos desenhos do arquiteto e que se replicou na historiografia da arquitetura. A forma de nomeação mais recorrente é adotar o sobrenome do encomendante, no entanto, sem a preposição “de”, por exemplo, Casa Czapsky ou Casa Millan². Em muitos casos, mesmo se a casa é vendida e passa a ser habitada por outras famílias, o título da casa permanece em referência ao encomendante original. Essa forma de nomeação permite refletir acerca da "operação de magia inerente a todo o ato de nomeação" (Bourdieu, 1989, p. 159), pois o que está em jogo é quem foi reconhecido como empreendedor simbólico da encomenda.

2Ainda que algumas célebres casas ficaram conhecidas por nomes que se valem de características do projeto, como a "Casa da Cascata", ("Fallingwater House", em inglês), projeto de Frank Lloyd Wright de 1936 para Edgar Kaufmann, ou a "Casa de Vidro", projeto de Lina Bo Bardi de 1950 para ela mesma e o marido. 
Nos casos em questão, observa-se que, na maioria deles, o título utilizado nas diversas fontes - nos registros imobiliários, nas listagens de obras do arquiteto e nas referências dos livros de arquitetura - se refere ao nome e sobrenome da figura masculina, a despeito da moradia representar, nesses casos, um projeto de reprodução familiar. Elas são assim denominadas: "Casa Febus Gikovate", "Casa David Rosemberg", "Casa Boris Fausto", "Casa Oduvaldo Vianna”, "Casa Juarez Brandão". Uma das biógrafas, por exemplo, filha do casal encomendante, faz referência à casa assumindo o nome que a história da arquitetura convencionou utilizar, isto é, apenas o sobrenome da figura masculina. Mesmo que a mãe tenha obtido bastante reconhecimento no meio artístico da época, e no de hoje, e mesmo que no momento da construção ela tenha sido responsável, como a filha revela, por financiar grande parte dos custos da moradia com seu trabalho, uma vez que o pai, mais novo em relação a mãe, ainda completava seus estudos em medicina, é exclusivamente o sobrenome do pai que a filha utiliza para se referir à casa. Trata-se de uma situação em que o discurso sobre a casa registrado na biografia da família incorpora a forma de nomeação estabelecida pela história canônica da arquitetura, reproduzindo uma versão da casa, a despeito do relato subjetivo e interno, dada pelo reconhecimento nas instâncias de consagração artística.

Nesse caso, e na maioria dos outros, o fato de estar ausente o nome da esposa é bastante significativo do apagamento da figura feminina, sobretudo quando se tem em vista que a data da encomenda é sempre muito próxima da mudança do estatuto matrimonial e, portanto, representaria um projeto, antes de tudo, de marido e esposa. Nos casos em questão, de famílias de classe média e alta com recursos suficientes para investir na construção de um bem para a família, a encomenda da casa coincidiu com os anos iniciais da vida de casados. Para eles, a construção do novo espaço físico representou a aliança do casal, marido e esposa, e esteve ligada à necessidade de um abrigo para os descendentes, com o intuito de perpetuar linhagens, tal como mostram trabalhos antropológicos sobre o significado da casa (Lamaison, 1987). Ao se fixar, no entanto, a figura masculina 
no título da moradia, é o homem que é entronizado na posição prestigiosa "de encomendante", como se ele fosse o único responsável. Consideradas as relações de poder, essa posição se replica também na pressuposta condição de que ele seria o "proprietário" e o "chefe da família". É ao homem que se atribui o papel superior de responsável financeiro e agente simbólico do empreendimento. Enquanto que o homem é colocado na posição elevada de mentor intelectual (encomendante), do responsável por arcar com custos (proprietário) e cabeça do lar ("chefe de família), a designação da mulher como "dona de casa" ou "do lar" faz referência direta a uma condição subalterna.

Contudo, vale destacar que, entre as casas estudadas, apenas uma delas foi designada com nome da encomendante, a "Casa Heloísa Alves de Lima e Motta”. Qual sentido social está nessa nomeação que traz embutida a efetiva ação da mulher? Essa casa corresponde a uma situação familiar específica: viúva, Heloísa encomendou a casa especialmente para ela e, eventualmente, para a frequentação dos filhos e netos, já crescidos. Seu relato biográfico, ao encarnar valores de independência e coragem, é expressivo da posição da mulher que assume um projeto desse porte como realização pessoal.

Por fim, o quinto ponto que merece ser ao menos tangenciado, embora não seja o tema específico deste artigo, é em relação à trajetória profissional dos arquitetos. Trata-se de um conjunto particular de produtores de bens simbólicos, cuja possibilidade de existência está diretamente relacionada ao processo de institucionalização da formação de arquitetura nas faculdades paulistas. Cabe sinalizar que esses profissionais, além da carreira liberal de arquiteto com escritório particular, possuíam em paralelo a carreira de docente da Faculdade de Arquitetura da Universidade de São Paulo. Combinaram, portanto, dois modos de atuação, a de técnico especializado e a de intelectual universitário. É a partir dessa inscrição institucional que eles foram reconhecidos como pertencentes a uma "escola de arquitetura", no sentido de um movimento estético e intelectual. Estar vinculado a uma instituição tão particular quanto a Universidade de São Paulo foi fundamental para a legitimidade da carreira e o reconhecimento artís- 
tico, pois o vínculo com um espaço altamente específico ${ }^{3}$, propulsor de projeto intelectual e cultural de formação de elites, possibilitou dar vazão a novos produtores de bens simbólicos e os aproximar de nova clientela afeiçoada a esses produtos (Rosatti, 2016).

Interessa também aqui ir além das considerações gerais que examinam as narrativas em conjunto e adentrar em alguns dos relatos produzidos pelos moradores, destacando dicções particulares nas formas de narrar a moradia. De modo a explorar com maior profundidade cada caso diferente, selecionei alguns trechos específicos de três das narrativas: duas delas são de mulheres, de posições sociais diferentes, sendo que uma é declaradamente engajada na militância comunista e a outra é herdeira de família aristocrática de tradicional. A terceira é de um homem, professor universitário e sociólogo.

\section{"A CASA MAIS MALUCA QUE VI NA MINHA VIDA"}

Entre os relatos coletados, a narrativa da jornalista Deocélia Vianna (1914-1985), Companheiros de Viagem, é a que explicita com maior potência os conflitos de gênero relativos à negociação entre o arquiteto e os clientes. Entre inúmeras passagens que contam a história da família, aparecem diversos episódios narrados em tom trágico-cômico que relatam a encomenda e construção da casa atravessada pelo jogo de disputa em que ela e o marido negociam com o arquiteto Vilanova Artigas, amigo da família e companheiro de militância de esquerda, o estilo, a decoração e a forma da futura residência do casal e do filho. No momento da encomenda, ela tinha 35 anos, seu marido, Oduvaldo Vianna (1892-1972), importante figura da dramaturgia brasileira, tinha 57 anos. Ambos tinham um filho com cerca de 13 anos, Oduvaldo Vianna Filho (1936-1974), que mais tarde viria se tornar o reconhecido autor de peça teatral, Vianinha.

A autobiografia fornece elementos que possibilitam situar essa família em um contexto mais amplo, do qual faz parte uma geração de artistas e profissionais da cultura responsáveis pela orga-

3Registro que a interpretação está inspirada na análise de Raymond Williams sobre o grupo Bloomsbury, estudo de referência sobre os vínculos entre vida intelectual, enraizamento na universidade e formação de novos padrões morais e estilos de vida (Williams, 1999). 
nização de domínios amplos como rádio, teatro, cinema, televisão, muitos dos quais também eram participantes da militância comunista. Essa geração de intelectuais e artistas engajados que, como apontaram Pontes \& Miceli (2012), teve que conciliar as aspirações contraditórias entre a inserção cultural e as apostas utópicas da transformação revolucionária.

Narrado sob o ponto de vista de uma mulher que se apresenta também na condição atuante no mercado de trabalho e engajada na militância feminista, o relato dá voz a dimensões de gênero que possivelmente não apareceriam se fosse feito pelas figuras masculinas da família Vianna, ambos com bastante legitimidade na carreira de escritores. Essa perspectiva, no entanto, também apresenta os dilemas da mulher moderna, dividida entre o mercado de trabalho, a função de esposa, de mãe e as obrigações domésticas. Essa posição fica visível quando a autora se identifica como "dona de casa", sobrecarregada pelas tarefas ligadas à limpeza e cozinha.

O relato que Deocélia Vianna faz da contratação do arquiteto é expressivo da combinação entre engajamento político e justificativas do privilégio. $\mathrm{O}$ texto possui tom bem-humorado e, em certa medida, irônico, em que ela deixa às claras as contradições de uma militante de esquerda empenhada em adquirir sua propriedade privada. Não se tratava, no entanto, de qualquer propriedade burguesa, e sim uma casa projetada em grande estilo. A ironia cortante aparece, por exemplo, quando afirma que o desejo dela, reconhecendo a origem humilde, era de ter uma casa, "como qualquer pequeno-burguesa" (Vianna, 1984, p. 120), ainda que a propriedade privada se apresentasse, para ela e o marido, ambos militantes bastante ativos do Partido Comunista, conforme define, como "um roubo".

A possibilidade de aquisição da propriedade é justificada pelo trabalho duro, tanto do marido, quanto dela. Ela desempenhava a atividade de escritora e jornalista dos Diários Associados, onde foi responsável por colunas de conselhos sentimentais direcionadas a mulheres, entre elas, o "Consultório Sentimental", que procurava dar conselho às consulentes com posicionamento feminista. Oduvaldo Vianna amealhou altas somas financeiras trabalhando nos setores de imprensa, rá- 
dio e televisão nas empresas de Assis Chateaubriand, onde ocupou posto de alto funcionário e também como escritor e dramaturgo.

Em relação às definições estéticas do projeto da moradia, Deocélia revela as expectativas do marido de ter uma casa moderna projetada pelo arquiteto amigo da família, Vilanova Artigas, escolha suntuosa que acabou por prevalecer em relação à dela, mais modesta e prática. Ela também revela que tinha papel rebaixado nas decisões e quase se submeteu às vontades do marido e às imposições do arquiteto:

"E aí começou o nosso, nosso não, meu drama. Por causa da casa, tive várias discussões com meu marido. Ele procurou o Vilanova Artigas, professor de Arquitetura, criatura maravilhosa. Seguindo a vontade de Oduvaldo, ele fez a planta mais maluca que já vi na minha vida. Talvez mais maluca do que a casa em que ele e a Virgínia moravam.”

Conforme relata, entendemos que um dos conflitos se refere ao tamanho e à ostentação da casa, que ela julga ser incompatível com a ideologia de esquerda e a posição militante do casal. Outro conflito é com o arquiteto que, segundo sua narrativa, desdenhava de suas opiniões ao se recusar a considerar suas sugestões em relação à funcionalidade dos espaços e à dificuldade de limpeza de certas soluções grandiosas da arquitetura moderna, como os grandes planos envidraçados. Também relata os conflitos em relação aos custos elevados para a construção da moradia, que priorizaria o requinte estético em detrimento à praticidade e à comodidade. A casa previa a instalação de grandes janelas nos espaços com pé-direito duplo, áreas ajardinadas, painéis de mosaicos de artistas e decoração com mobiliário de designers modernos. Em suas palavras:

"Artigas acabou brigando comigo, eu não tinha que dar palpites, eu não entendia de construção, eu era burra. E haja dinheiro para os empreiteiros [...] Eu já me recusava a morar na casa, onde seria preciso um mordomo de luvas e tudo, coisa que não coincidia com a nossa maneira de pensar" 
Do ponto de vista formal, a nova residência era bem diferente das demais moradias do entorno, o que causava estranhamento na vizinhança. Com humor, ela conta que por vezes alguém perguntava se ali era um abatedouro ou uma fábrica. Ainda que a casa de tão grande parecesse ser um galpão comercial, Deocélia reclama da exiguidade dos espaços privados. Os dormitórios do casal e do filho eram muito pequenos e ambos compartilhavam apenas um banheiro, distante, portanto, dos padrões de luxo e conforto das tradicionais residências burguesas, que individualizam os espaços de intimidade. O tamanho da cozinha é também criticado. Segundo sua descrição, era um espaço pequeno e pouco funcional para ela que desempenhava a função de dona de casa. Já os setores de estar e lazer, característicos de residências de grupos habituados a promover jantares e festas com muitos convidados, eram grandes e monumentais, o que desagrava pois se desperdiçava espaço com a área de circulação:

"Achavam a casa com jeito de tudo, menos de uma casa familiar... Pois a nossa tinha $500 \mathrm{~m}^{2}$ de área construída e apenas dois quartinhos pequenininhos, que mal davam para nós (...), e um banheiro com chuveiro. Metade da construção era em rampas, um salão de $8 \times 6 \mathrm{~m}$, outro de $5 \times 4 \mathrm{~m}$, áreas lajotadas, a cozinha, mirradinha também, era na frente da casa, dando para a rua. Para uma dona de casa, um horror!”

A casa moderna, para essa geração diplomada, altamente cultivada e engajada, representou a conversão material do capital econômico acumulado com o trabalho em profissões intelectuais, a de jornalista e escritores. É também a transfiguração estética de um projeto que é também político e intelectual. Nesse caso, além de ser o espaço privado de reprodução familiar, a casa se apresenta como a escolha de uma imagem pública, que visivelmente explicita os engajamentos e aquisições culturais da família. A escolha pela arquitetura sem ornamentos - sem as amarras simbólicas associadas aos elementos decorativos das frisas, colunatas e motivos historicistas, comumente apreciados pelo gosto convencional da aristocracia do café em declínio ou da burguesia empresarial - representa a afirma- 
ção de uma postura progressista e culturalmente bem informada. A moradia moderna serviria como um espaço simbólico, suporte físico e cultural de socialização dos filhos em círculos de esquerda e para transmissão de certa relação engajada com a cultura.

A questão da transmissão do patrimônio cultural associado ao patrimônio imobiliário aqui se faz de forma explícita. A trajetória artística de Oduvaldo Vianna Filho, o Vianinha, autor de peças de teatro, como o pai, é expressiva da transmissão familiar. Herdeiro tanto da tarefa de criação artística quanto da prática militante, a socialização familiar serviu como oportunidade para ingressar na corporação teatral e para construir um certo imaginário popular - em contato com a esquerda, mas longe das camadas operárias - com o qual escreveu, por procuração, peças de teatro a serviço da causa dos mais pobres (Pontes \& Miceli, 2012).

\section{CASA DE PRAIA, SOCIABILIDADE ARISTOCRÁTICA E MITO BANDEIRANTE}

Completamente diferente da narrativa nostálgica da senhora que revive romanticamente a fase adolescente, evocando como usufruía a casa na condição de filha, as memórias da herdeira aristocrática e sobrinha do presidente Washington Luís, Heloísa Alves de Lima e Motta (1904-2002) apresentam o olhar de uma senhora de 87 anos que, receando a "fraqueza da memória", conta em sua biografia o percurso de uma ilustre descendente de grupos proprietários e dirigentes políticos paulistas. Ricas fazendas, mansões urbanas, pessoas notáveis, festas luxuosas, viagens para o exterior, consumo conspícuo, hábitos diferenciados, apreço por móveis, louças, valores europeus e o uso frequente de expressões de língua francesa estão presentes na autobiografia publicada em 1992. O título sugestivo, Uma menina paulista, coloca em evidência o orgulho de pertencimento ao estado de São Paulo, narrado em tom glorioso. Os episódios relatados revelam as bases materiais e os valores simbólicos que sustentaram essas famílias da elite, agrupando um conjunto de

4 MOTTA, Heloísa Alves de Lima. Uma menina paulista. São Paulo, Totalidade Editora, 1992, p. 101. 
reminiscências por meio das quais a autora declara o orgulho de ser descendente da aristocracia paulista, reverenciando o passado quinhentista e a valentia bandeirante.

É apenas nas páginas finais que a narradora cita, de passagem, a casa que encomendou ao arquiteto Paulo Mendes da Rocha em 1961, mesmo ano em que ele havia sido condecorado na VI Bienal Internacional de Arte de São Paulo pelo arrojado projeto da cobertura do Clube Atlético Paulistano, seletivo espaço de sociabilidade mundana da elite paulistana. Reconhecido pela afirmação do estilo que se convencionou chamar na historiografia da arquitetura de "Brutalismo Paulista", Mendes da Rocha foi contratado para fazer o projeto da residência de veraneio, em Ilhabela, reputado espaço de vilegiatura paulista. Conforme informa, Heloísa decidiu construir a nova casa com o dinheiro do aluguel de sua grande chácara em Santo Amaro, na capital paulistana. Diferente de Deocélia, que tinha profissão de jornalista e ocupação assalariada no mercado de trabalho, Heloísa, na condição de rentista, extraía suas fontes financeiras do patrimônio imobiliário herdado da família.

A casa que ela encomendou distingue-se das outras casas aqui listadas: quanto à localização, não se trata de uma casa urbana, na capital; quanto à função, não se trata da moradia principal de uso cotidiano; e quanto ao momento de construção, não se trata de uma casa construída para inaugurar a vida de casal e fundar uma nova família, na expectativa de chegada dos filhos. Trata-se de uma casa de praia, cuja esporadicidade da utilização nos momentos de lazer parece se ajustar bem à escolha por uma arquitetura despojada e rústica, sem comprometer o estilo de vida luxuoso que sua proprietária levava na capital.

A casa em Ilhabela não seria espaço de reprodução da família, mas sim locus da sociabilidade distintiva da encomendante. Foi projetada com intuito de acolher familiares e receber pessoas ilustres em jantares elegantes a altas rodas sociais. Conforme relata, em sua casa chegou a hospedar o então governador da época, Paulo Egydio Martins e a oferecer jantares e festas que eram frequentados pelos descendentes da antiga aristocracia paulista, com a presença de filhos, netos e bisnetos de figuras que ela, na narrativa, faz ques- 
tão de identificar ressaltando os títulos nobiliárquicos, um visconde, uma condessa, um barão, "todos oriundos do grande bandeirante paulista José Estanislau de Mello Oliveira” (1992, p. 98).

Diferente também dos outros projetos, essa casa aparece na historiografia intitulada com o nome da cliente, uma mulher, ou seja, é designada pelo nome da proprietária e também autora da encomenda. Comparada a outras residências do período, essa situação é rara, já que pressupõe a condição de agente principal da contratação do arquiteto. Por outro lado, nesse caso, cabe destacar que o fato da casa ser nomeada no feminino é indício relevante da situação matrimonial do momento da encomenda. Heloísa iniciou sozinha o projeto de construção da residência em 1961, com idade superior a 55 anos, a esta altura já viúva e mãe de 5 filhos adultos e também avó de 6 crianças, momento da vida que lhe permitiu se aventurar de forma independente em novos projetos. Para ela, o discurso sobre a casa está investido de independência e bravura, o qual se apresenta como um projeto de realização pessoal dignificante e também uma forma de homenagear seus ancestrais. Seu marido havia morrido em 1938, quando ela tinha apenas 34 anos, deixando-a com os filhos pequenos. Na autobiografia, a situação inesperada da viuvez precoce aparece como infortúnio que a teria impulsionado a garantir sozinha a existência da família. A tônica da narrativa é o percurso de uma mulher forte e independente, orgulhosa de seu passado e agente de seu futuro.

Os episódios sobre a casa metaforizam essa condição. A figura da mulher autônoma, com iniciativa e opinião própria está explicitamente presente no relato sobre a construção da casa. Heloísa menciona que se tratava de uma casa de fim de semana "muito repousante", localizada à beira-mar e, de forma muito sucinta e firme, define o estilo estético que optou por construir: "uma cópia da Casa do Bandeirante". Essa escolha estética não é fortuita. Provavelmente inspirada na casa em estilo bandeirista remanescente do período colonial brasileiro, localizada no bairro do Butantã, próximo ao rio Pinheiros, a Casa do Bandeirante se tornou símbolo do início da formação da cidade de São Paulo, reinventada como lugar de memória no contexto da comemoração do IV Centenário da Cidade de São 
Paulo (1954), alguns anos antes da encomenda de sua própria casa. Apresentada como registro autêntico das construções paulistanas, o estilo bandeirista simbolizava o espaço original de fixação na cidade e de conquista de novas terras.

No relato de Heloísa, a memória comemorativa da cidade de São Paulo é reapropriada em narrativa pessoal, recurso de deslocamento que é uma maneira inequívoca de estima de si e senso de virtude. Quando faz balanço de sua existência narrando sua implicação direta no projeto da nova residência, ela faz coincidir sua história individual com a história oficial, recurso daqueles que se reconhecem em posição dominante.

$\mathrm{O}$ arquiteto contratado para o projeto foi Paulo Mendes da Rocha, reconhecido pelo estilo sóbrio e postura autoral radicalmente moderna. Embora não sejam expostos detalhes da contratação do profissional - não sabemos se era alguém de sua rede de amizades ou profissional cujo estilo apreciava -, também não são fornecidas informações mais detalhadas sobre os espaços internos da casa, a distribuição dos espaços, a quantidade de cômodos ou as escolhas em matéria de decoração. Mas o que chama atenção é a preferência pelo estilo em homenagem ao passado nobre, que destoa da atribuição de vanguardista conferida ao arquiteto. Com orgulho, Heloísa refere-se à casa dizendo que ela era "cópia" do estilo bandeirista: ela optara pela reprodução de um exemplar mítico e altamente carregado de significado.

O que vemos é que o apelo ao modelo estético da habitação bandeirante se concilia com o estilo de vida e visão de mundo com os quais a encomendante quer se representar. Ao longo de toda autobiografia, elementos da ideologia bandeirantista são reativados para valorizar as origens e contar as glórias da família de fazendeiros de café do interior do estado de São Paulo, exaltados pela coragem do paulista, visto como desbravador e trabalhador.

Como balanço das aventuras e conquistas da família, o relato da construção da casa moderna em estilo bandeirista se situa nas páginas finais do livro. É bastante significativo que o projeto da casa tenha sido o episódio de encerramento pois, no curso de sua vida, a nova casa, projetada em 1961, está cerca de trinta anos do momento atual em que se encontra a autora, quando escreve suas memórias, 
em 1992. Se é escolhido como episódio final de seu percurso de vida, talvez seja pelo sentido apoteótico que o projeto residencial ocupa na narrativa. Mais uma vez, Heloísa retoma a versão de triunfo dos paulistas, desta vez orientada a si mesma.

Sobre o período de construção, a encomendante nos oferece um relato em tom de façanha, ao exaltar a figura de mulher audaciosa e batalhadora que esteve no canteiro de obras semanalmente. Em suas palavras, "eu mesma dirigindo" de perto todo o processo: acompanhou a obra, fiscalizou os detalhes e vigiou o serviço dos pedreiros. Heloísa justifica-se afirmando que "isto era necessário pois os caiçaras são muito tranquilos e precisava estar em cima, caso contrário jamais ficaria pronta; assim mesmo levou quase um ano"s. Os trabalhadores estão ali identificados com o termo "caiçara" e são associados ao sentido depreciado do ócio, remetendo-os à ideia de passividade e indolência. A proprietária, em contraste, faz apologia ao trabalho e toma para si as qualidades de vigor, tenacidade, bravura. Certamente, do ponto de vista das questões de gênero, é um relato divergente das representações do papel da mulher moderna emancipada, sobretudo porque nesse caso se sobrepõem aos marcadores de classe social. Os valores de coragem e independência dizem respeito, especialmente, à condição de herdeira da aristocracia rural paulista.

Sobre os deslizamentos entre casa e narrativa de vida, vale deixar indicado que ao longo da narrativa é apresentada, como fio que estrutura o relato, a sequência das casas em que habitou: a casa-grande, o palacete, a mansão, a casa bandeirista. Além disso, a capa do livro também foi ilustrada com desenho da casa que habitou na infância, um palacete eclético na capital paulista. Antes dele, ela tinha morado com os pais na casa-grande da fazenda, no interior do estado, onde a família era proprietária de fazendas de café.

A mensagem deixada na dedicatória do livro é mais um elemento-chave para compreender o sentido alargado que a ideia de casa representa na construção de seu percurso de vida. A autora declara na abertura de suas memórias: "dedico este livro a meus filhos, meus netos e bisnetos e, com grande amor, desejo que continuem sempre 
unidos e que amem a casa em que nasceram". Trata-se, pois, de uma narrativa de quem tem consciência da herança que carrega e, com orgulho, constrói o percurso de vida renovando suas raízes. O uso da palavra "casa" é explícito e dele pode-se extrair dois sentidos largamente evocados ao longo do livro. A casa narrada adquire tanto a conotação de patrimônio material quanto simbólico: ela é signo da herança econômica e também é metáfora da família com linhagem nobre, que realiza a transmissão de valores aristocráticos por sucessivas gerações.

\section{UMA "DENÚNCIA", UMA “AGRESSÃO" E UMA "CONCES- SÃO AO PRESENTE"}

Se no caso de Heloísa Alves de Lima e Motta a casa narrada representa a bravura da mulher paulista independente, no relato em primeira pessoa de Juarez Brandão Lopes a casa aparece como materialização de expectativas de transformação social. Sociólogo formado em 1950 na Escola de Sociologia e Política, no momento da encomenda, no agitado ano de 1968, Brandão já era docente da Universidade de São Paulo, o que explica a localização urbana muito próxima ao campus universitário.

O ponto significativo do relato sobre a casa que construiu para si e a família é que se trata, ao mesmo tempo, de um testemunho pessoal e de um ensaio analítico. Sua visão sobre a casa traz a condição de um sociólogo que pensa as mudanças na sociedade capitalista. Ali aparece a ambiguidade entre aposta pessoal, marcada pelas promessas sociais e políticas do período, e exame sociológico do presente, que o coloca consciente da impossibilidade de mudança rápida da estrutura de hierarquias da sociedade brasileira.

O local e a época de publicação do ensaio são marcas expressivas dessa dupla inscrição. $\mathrm{O}$ texto foi publicado na quarta e última edição da Revista $O u^{6}$, periódico que existiu entre agosto de 1970 e junho de 1971, sob organização dos estudantes do Grêmio da Faculdade de Arquitetura e Urbanismo da Universidade de São Pau-

6 A revista era organizada por alunos da graduação engajados na militância política contra o regime militar, e o momento político era de contestação da atuação profissional e radicalização política, no qual alguns arquitetos buscavam formas de engajamento, como anuncia Lefèvre, "em substituição do lápis”. LEFÈVRE, Rodrigo. “A casa do Juarez”. Revista Ou..., n 4, GFAU, jun. 1971, sem página. 
lo. Nessa escola, Juarez Brandão atuava como docente no grupo de disciplinas de estudos socioeconômicos. O contexto da publicação reitera o tom reivindicativo e contundente do testemunho, momento de crítica à ditadura militar e de radicalização política.

$\mathrm{O}$ volume da revista em questão, dedicado ao problema da habitação popular no Brasil, abria-se com editorial de duas páginas, a partir do qual a equipe responsável - cujos membros são apenas identificados por apelidos despojados ou prenome - alertava para os dados alarmantes de pobreza urbana e desigualdade social, e criticava a falta de engajamento das escolas de arquitetura e dos arquitetos em propor soluções contra o déficit quantitativo e qualitativo de moradias nos centros urbanos e nas áreas rurais. É nessa edição transbordante de engajamento que aparecem dois pequenos textos sobre a casa projetada pelo arquiteto Rodrigo Lefèvre (1938-1984) para o amigo Juarez Brandão Lopes (1925-2011), ambos docentes da mesma instituição. Tanto o arquiteto quanto o encomendante escreveram algumas linhas explicitando suas ambições, expectativas e vicissitudes quanto à moradia.

Com título que revela intimidade de amigo, o pequeno artigo de Rodrigo Lefèvre, "A Casa do Juarez", se apresenta na forma de um manifesto. Ainda que o tema seja a casa que projetou, o texto está organizado com a enumeração de diversos pontos em que se destacam, em tom de tarefa política, aspectos fundamentais para ação dos arquitetos. Descontente com o estatuto da profissão, o arquiteto se coloca na posição de identificar problemas sociais e urbanos do país, definir as necessidades da população e propor possibilidades de transformação da sociedade. O horizonte de intervenção é amplo e coletivo, o que faz saltar à vista a discrepância em relação à solução da moradia individual e burguesa, implicada em uma resposta individual e autoral por parte dos arquitetos. "Agressão" é o termo utilizado pelo arquiteto para se referir à residência e assim demarcar sua posição crítica em relação à sua categoria profissional.

A solução construtiva para a casa que o arquiteto propõe para o encomendante é artesanal. Para Lefèvre, essa solução não industrializada e destinada a uma única família estaria, mesmo assim, 
sobrecarregada da dupla tarefa estética e política. Na visão do arquiteto, sua proposta formal - uso de materiais rústicos, recusa de acabamentos - se apresenta como uma forma radical de denúncia à propriedade privada, que impõe o parcelamento da cidade em pequenos lotes urbanos. Conforme reivindica, a linguagem arquitetônica - abóboda na cobertura, tubulações elétricas e hidráulicas aparentes e ausência de revestimento nas paredes - pretenderia se colocar na contramão do que é considerado "bonito", entendido como o gosto estabelecido e convencional, ainda que o arquiteto esteja consciente que tal audácia formal corra o risco de perder a sua atribuída carga crítica e, possivelmente, a sua força diferencial ao "ser absorvida como modismos". Como uma proposta experimental e consciente da limitação em relação à solução do problema de moradia no país, faz uso de um modo de produção manufaturado, ainda que a intenção, a longo prazo, fosse idealmente pensar numa técnica apropriada para realização de larga escala com produção industrializada.

Observando os argumentos com a distância temporal, parece evidente o descompasso entre o diagnóstico dos problemas sociais do país, as soluções imaginadas e a efetiva produção da casa exclusiva do amigo. A situação seria semelhante em relação à construção civil, setor em que os arquitetos acreditavam ser central para o desenvolvimento das forças produtivas. Os empresários industriais não tinham consolidado valores compatíveis com a formação de uma classe nem projeto de industrialização nacional que abrangesse essa cadeira do setor produtivo. Ainda que os arquitetos contassem com isso, a aposta na racionalização da construção civil, com produção em larga escala das moradias, fazia água.

As reflexões de Brandão sobre sua própria moradia, diferente das feitas pelo arquiteto, não se apoiam na expectativa da industrialização ou da transformação da consciência de classe dos trabalhadores. Ao falar de sua casa e das experiências como morador, o sociólogo enfoca mudanças no espaço privado, destacando a reconfiguração das obrigações na gestão do ambiente doméstico. Aponta, por exemplo, as novas divisões de trabalho entre marido e esposa, uma vez que a mulher de classe média então passava a ter profissão 
e trabalhar fora de casa. Na negociação dessas novas relações de gênero, aparece um desconforto, que é a presença e a necessidade da empregada doméstica. Segundo o relato do sociólogo, essa presença não seria coerente com a proposta arquitetônica da casa, que radicalmente questionava as relações de opressão e as formas de exploração do trabalhador subalterno. No entanto, a despeito da crítica, Juarez Brandão é cauteloso em dizer que projeto solicitado ao arquiteto previu a construção de um dormitório para abrigá-la em tempo integral no domicílio. Se a sociedade urbano-industrial aponta para mudanças em relação à profissionalização das relações de trabalho e aumento das demandas por direitos sociais, a necessidade de empregada doméstica persiste e se impõe para famílias de classe média e alta, cujas mulheres assumem postos no mercado de trabalho. Seu relato expressa esse incômodo, ao mesmo tempo que assume que é uma comodidade que não poderia dispensar:

"No mínimo, a relação com elas deveria ter-se reduzido, para completa coerência com a arquitetura, à pura relação contratual de trabalho: as empregadas domésticas com funções definidas, horário certo e que, claro, não moram no emprego. A cozinha é apenas local de trabalho, pensada para isso, com todas as conveniências modernas que poupam trabalho (se ainda não existem, deveriam existir). Vem à mente a atividade doméstica da esposa que, por trabalhar fora, precisa ser diminuída ao mínimo ou a da empregada que, numa sociedade industrial, é cara e tem reivindicações crescentes. Não são, cozinha nem quintal, ambiente de viver de empregadas, parte da família, na relação de subordinação tradicional. Neste sentido, o quarto de empregada choca, parece-me, propositalmente e talvez em mais de um sentido: simplesmente não deveria existir; é concessão irrecusável ao presente, que demora a se transformar num futuro próximo, já claramente percebido!"’

7Cf. Lopes, 1971. Convém deixar sinalizado que a publicação era uma produção estudantil que tomava partido dos conflitos do período. O nome da revista é um claro posicionamento em relação ao embate que se formou na FAU, colocando de um lado os favoráveis ao "desenho", ratificando a postura de Artigas e os que defendiam o "canteiro", capitaneados por Ferro, Lefèvre e Império, então docentes na FAU. "Ou..." faz alusão a uma outra possibilidade de atuação dos arquitetos que questionasse a exclusividade do desenho. 
Em relação aos outros depoimentos sobre a moradia moderna recolhidos, o testemunho de Juarez Brandão foi aquele realizado mais próximo do momento da inauguração da casa. Recém instalado com a família, esposa e filhos, e em momento de intensa atividade profissional e política, com a participação na fundação Cebrap (Centro Brasileiro de Análise e Planejamento ${ }^{8}$ ) e na universidade, suas declarações evidenciam o encantamento pelo projeto, a confiança nas ideias do arquiteto, no partido arquitetônico proposto e a expectativa, talvez ingênua e sincera, de que aquela proposição espacial pudesse produzir novas relações sociais. Ainda assim, diferente do arquiteto, desconfia da possibilidade de mudanças radicais, pois reconhece que o projeto encontra limites na sua própria realização.

\section{HABITAR E NARRAR A MORADIA MODERNA}

As moradias referenciadas nos relatos foram construídas entre o final dos anos 1940 e início dos anos 1960, foram celebradas pelo arrojo estético, passaram a fazer parte da história da arquitetura moderna brasileira (Bruand, 1999; Acayaba, 2011; Segawa, 2002, Koury, 2003, Bastos \& Zein, 2010). Os arquitetos que as projetaram foram tomados como produtores de destaque no cenário brasileiro, valorizados pela aposta na elaboração de nova uma linguagem formal e um ousado agenciamento dos espaços. Interessados em conquistar um nome (uma assinatura), um lugar de prestígio na carreira (estatuto artístico e autoral da profissão) e disseminar as crenças ideológicas que os guiavam, esses profissionais conceberam projetos residenciais com a dupla tarefa, a de tomada de posição em relação a outros produtores de arquitetura e a de manifesto político-estético. As propostas despertaram o interesse de clientes que, muito próximo a seus círculos sociais, acolheram as ideias, muitas vezes completamente, outras com certa desconfiança, como mostra a demanda por uma casa bandeirista. Essa casa em Ilhabela, de Heloísa Motta, largamente destoa da produção brutalista de Paulo Mendes da Rocha. 8 O Cebrap foi fundado em 1969 por intelectuais, entre eles sociólogos, filósofos, cientistas políticos e demógrafos, em sua maioria egressos da Universidade de São Paulo, em um momento de afastamento desses quadros da instituição, por conta do regime militar. Sobre o Cebrap, cf. Montero \& Moura, 2009. 
De todo modo, a clientela se mostrou disposta a dar caução financeira e simbólica a novas formas de morar, sejam aquelas que remetiam ao passado ou aquelas com expectativas de mudança do futuro.

Os relatos coletados, em sua maioria, referem-se a moradias modernas, no sentido de movimento estético, sobretudo atrelado a uma vanguarda arquitetônica e, em relação à proposta formal, construtiva, estética e de agenciamento dos espaços internos, distanciaram-se dos modelos convencionais praticados no período. A escolha pela arquitetura moderna de vanguarda fica evidente quando se tem em conta que, dentre a oferta de estilos disponíveis para camadas médias e altas que amealharam algum recurso financeiro, esses encomendantes rejeitaram as possibilidades mais correntes, como o ecletismo, a aplicação dos modelos neoclássicos, art déco e outros estilos da moda, como os chalés normandos. A única casa que adota concepção passadista, no caso, o estilo neocolonial, foi escolhida por uma herdeira de família aristocrática, certamente concessão do arquiteto às demandas de representação simbólica da cliente.

Em termos gerais, os arquitetos encontraram clientes para os quais puderam fornecer o modelo moderno em sua expressão mais visível: linhas geométricas, volumes puros, cobertura plana ou em abóbodas, com a presença de espaços internos amplos e interligados, iluminados por grandes janelas, extensos painéis de vidro e com a utilização de materiais brutos, sem acabamento ou revestimento, como cimento, ferro, além de tubulações elétricas e hidráulicas expostas. Trata-se de uma clientela com condições sociais bem específicas, com capacidade financeira de pagar por um serviço especializado e com condições culturais privilegiadas, o que mostra o empenho em se fazerem representar a partir do espaço de moradia

Considerando o discrepante cenário social da São Paulo da metade do século XX, quando o processo de modernização e industrialização se intensifica, e junto a ele o crescimento da pobreza em bairros periféricos, estamos falando, manifestamente, das condições de investimento de ínfima parcela da população paulistana (Kowarick et al., 1976). A fim de construir moradias unifamiliares com a contratação de um serviço profissional raro e exclusivo para projetar 
formas arrojadas, esses clientes optaram por adquirir lote individual nos novos bairros horizontalizados e estritamente residenciais da cidade. São casas que, embora com linguagem estética despojada, possuem o refinamento de um projeto arquitetônico de vanguarda, que é, sobretudo, um projeto intelectual. Além disso, contam com padrão elevado de conforto moderno, com rede de energia elétrica, água encanada, banheiros internos, chuveiro, ventilação e iluminação natural, além de cômodos especializados e espaços para diversas atividades (sala de estar, sala de jantar, cozinha, lavanderia, quarto para o casal, quartos para os filhos, biblioteca/escritório, área para empregados, garagem, jardim e piscina em alguns casos), diferenciando-se amplamente da situação de habitação de grande parte da população no mesmo período 9 .

\section{RELÍQUIAS DA CASA MODERNA: CONSIDERAÇÕES FINAIS}

As narrativas aqui levantadas contribuem para explorar a ideia de que a casa não é apenas uma materialidade arquitetônica, mas um espaço físico, social, mental e simbólico constituidor e constituído de socializações múltiplas. É notadamente nesse sentido que o estatuto das narrativas biográficas dos moradores possui valor heurístico. Ao narrar suas vidas referenciando-as às formas de habitar, esses clientes constroem versões de si e dos locais sociais que ocupam. A partir de uma particular relação com a casa, tais fontes ganham inteligibilidade à luz da experiência vivida. Cada uma das narrativas, como se viu, inclui um ponto de vista sobre a casa moderna que corresponde às diversas esferas sociais que participaram. Na casa estão materializadas suas representações sociais, seus engajamentos políticos, suas posturas estéticas: são maneiras de habitar o mundo adquiridas no seio familiar, no percurso escolar, na carreira profissional e nos circuitos culturais que frequentaram.

Em conjunto, os relatos fornecem elementos das múltiplas e por vezes ambíguas significações do habitar moderno. Tomado como material empírico, esses relatos são fonte privilegiada de conhecimento listana que se formava, cf. Pierson, 1939, 1942. 
de realidades sociais, possibilitando complexificar, a partir do ponto de vista do morador, o processo de modernização expresso nas formas de habitação. Mais do que isso, em se tratando de narrativas em primeira pessoa, elas trazem o ponto de vista singular dos moradores, deixando entrever a posição que ocupam na hierarquia econômica e simbólica.

Portanto, é importante ponderar que a existência de escritos biográficos sobre a casa moderna mostra que essa clientela também esteve em condições especiais de transformar em linguagem e compartilhar essa experiência do morar. Trata-se da condição, inerente ao ato de narrar, de enunciar um relato como testemunha e personagem, ou produtor e produto, com vistas a registrar, justificar ou rememorar as escolhas que fizeram. Nesse sentido, é instigante a pergunta colocada por Daniel Fabre, Jean Jamin \& Marcello Massenzio: "Quem numa sociedade pode obter acesso ao discurso biográfico na qualidade de sujeito e na qualidade autor?"10.

Essa questão basilar permite demarcar a especificidade do lugar social que essa clientela ocupa, uma classe média-alta intelectualizada e de posse de capitais culturais diversificados, e sinalizar, de passagem, para efeitos do que vem sendo enfocado neste artigo - as relações entre trajetória de vida, a construção da casa e a narrativa sobre ela - um exemplo em contraponto. No mesmo período do final dos anos 1950 e na mesma cidade de São Paulo, Carolina Maria de Jesus, mulher, pobre, negra, migrante e favelada, descreveu suas experiências e sofrimentos como moradora da favela do Canindé. $\mathrm{O}$ diário, publicado em livro com o título Quarto de Despejo, não por acaso espaço da casa alusivo ao lugar de rejeição social que ocupa, é expressão contundente de sua condição marginalizada ${ }^{11}$. Num misto entre memórias e documento histórico, o material foi editado em livro e alçado à condição de narrativa literária. Isto dito para realçar que as condições de possibilidade de habitar, narrar e construir uma estória não são universais e estão submetidas a situações e contextos que tor-

10 Tradução nossa, do original: "Qui peut accéder dans une société à la maîtrise du discours biographique en tant que sujet et en tant qu'auteur?". (Fabre, Jamin \& Massenzio, 2010, p. 12)

11 Acrescento que, após estrondoso sucesso do primeiro livro, o título da segunda publicação de Carolina de Jesus, Casa de alvenaria: diário de uma ex-favelada, mais uma vez guarda relação com a moradia, registrando metaforicamente, pela conquista da casa própria (com diversos cômodos e não apena um "quarto de despejo", de material sólido e não mais um barraco de madeira), a ascensão social que o reconhecimento como escritora lhe trouxe. Cf. Jesus, 1960, 1961. 
nam lícito, admissível ou literariamente apreciável contar uma vida.

Por fim, cabe acrescentar que a casa narrada pelos moradores já não é mais a casa concebida pelo arquiteto. Filtrada pela memória e transformada em palavras, ela se distancia do objeto arquitetural construído. Ela é espaço apropriado, vivido, imaginado e reinventado. E isso fica explícito nas diferentes formas como ela aparece: expectativa de transformação revolucionária, nostalgia da infância, manifestação de conflito de gênero, desejo de ousadia estética, investimento econômico, herança imobiliária, transmissão do passado glorioso aristocrático, afirmação de um projeto de independência, rejeição aos modelos burgueses de conforto, crítica social ao presente, manifesto de uma utopia, entre outras representações e idealizações.

Oscilando entre a apologia ao vanguardismo arquitetônico e a queixa dos infortúnios de se habitar uma casa fora dos padrões convencionais, reivindicando a posição de denúncia contra a exploração do trabalhador ou reafirmando o legado paulista glorioso, essas narrativas e memórias permitem acessar o imaginário e as ambições de seus moradores, as motivações que os levaram a empreender esse projeto, as decepções e os triunfos angariados na convivência familiar. Também apresentam observações agudas da vida cotidiana e das constrições históricas do momento, a partir das quais são possíveis de apontar marcadores de classe, gênero e idade, assim como posições estéticas e políticas de um novo grupo social específico em busca de diferenciação. Constituidoras da experiência cotidiana e fundamentais para a instauração do lugar social de seus moradores, essas casas foram materialmente construídas e habitadas, simbolicamente reconstruídas em memórias e literariamente narradas. Assim, o discurso sobre a casa pode ser tomado como um modo refinado de apropriação e reconstrução. A experiência vivida e narrada mostra que as visões de mundo e estilos de vida estão diretamente conectados aos modos de morar. Traduzida em linguagem, a moradia responde mais uma vez ao desejo de construção da imagem que melhor manifesta o modelo social, entre vários, a que desejam se conformar. 


\section{REFERÊNCIAS}

ACAYABA, M. Residências em São Paulo. São Paulo: Romano Guerra Editora, 2011.

BASTOS, M. A. J.; ZEIN, R. V. Brasil: arquiteturas após 1950. São Paulo: Perspectiva, 2010.

BECKER, H., Biographie et mosaïque scientifique. Actes de la recherche en sciences sociales, Paris, v. 62/63, pp.105-110, 1986.

BESSIN, M. Parcours de vie et temporalités biographiques : quelques éléments de problématique. Informations sociales, v. 156, pp. 12-21, 2009.

BOURDIEU, P. L'Illusion biographique. Actes de la recherche en sciences sociales. Paris, v. 62/63, pp.69-72, 1986.

BOURDIEU, P. Un placement de père de famille. La maison individuelle, spécificité du produit et logique du champ de production. Actes de la Recherche en Sciences Sociales, Paris, v. 81/82, pp. 6-33, 1990.

BOURDIEU, P. A casa kabyle ou o mundo às avessas. Cadernos de Campo, São Paulo, v. 8, nº. 8, pp.147-159, 1999.

BOURDIEU, P. As estruturas sociais da economia. Porto: Campo das Letras, 2006.

BOURDIEU, P. O poder simbólico. Lisboa: Difel; Rio de Janeiro: Bertrand, 1989.

BURKE, P. Gilberto Freyre e a nova história. Tempo Social, São Paulo, v. 9, no. 2, pp. 1-12, 1997.

BRUAND, Y. Arquitetura Contemporânea no Brasil. São Paulo: Perspectiva, 1999.

CARVAlHO, V. C. de. Gênero e artefato: o sistema doméstico na perspectiva da cultura material - São Paulo, 1870-1920. São Paulo: Edusp; Fapesp, 2008.

CERTEAU, M. A invenção do cotidiano. Morar, Cozinhar. Rio de Janeiro: Vozes, 2013.

CHARLE, C. Situation spatiale et position sociale. Actes de la recherche en sciences sociales. Paris, v. 13, pp. 45-59, 1977.

DUBAR, C. e NICOURD, S. Les biographies en sociologie. Paris: Éditions La Découverte, 2017.

DURAND, J. C. Arte, privilégio e distinção: artes plásticas, arquitetura e classe dirigente no Brasil, 1855/1985. São Paulo: Perspectiva; Edusp, 1989. 
ELEB, M. Les 101 mots de l'habitat à l'usage des tous. Paris: Archibooks, 2015.

ELEB, M. Se construire et habiter: propositions d'analyse psychosociale clinique. 1980. Thèse (Doctorat de Troisième Cycle en Sociologie de la Connaissance et des Idéologies), Paris, Université Paris VII.

FABRE, D.; JAMIN, J. et MASSENZIO, M. Jeu et enjeu ethnographiques de la biographie, L'Homme, v. 195-196, nº. 3, pp. 7-20, 2010.

FAUSTO, B. Memórias de um historiador de domingo. São Paulo: Companhia das Letras, 2010.

FREYRE, G. Casa-Grande e Senzala: formação da família brasileira sob regime patriarcal. 51 ${ }^{\mathrm{a}}$ Edição. Rio de Janeiro: Global, 2006.

FREYRE, G. Sobrados e Mucambos: decadência do patriarcado rural e desenvolvimento urbano. 15 ed. revista. São Paulo: Global, 2004.

HOWARD, E. Cidades-Jardins de amanhã. São Paulo: Hucitec, 1996

JESUS, C. M. de. Casa de Alvenaria: diário de uma ex-favelada. São Paulo: Ed. Francisco Alves, 1961.

KOURY, A. P. Grupo Arquitetura Nova. São Paulo: Romano Guerra, 2003.

KOWARICK, L. et al. (org.). São Paulo, crescimento e pobreza. São Paulo: Ed. Loyola, 1976.

LE GOFF, J. Comment écrire une biographie aujourd'hui ? Le Débat, Paris, v. 54, pp. 48-53, 1989.

LIRA, J. T. C. de; NASCIMENTO, F. B. do; SILVA, J. M. de; RUBINO, S. B. Domesticidade, Gênero e Cultura Material. São Paulo: Edusp/ CPC, 2017.

LOPES, J. B. Desenvolvimento e mudança social: formação da sociedade urbano-industrial no Brasil. São Paulo: Editora Nacional, 1976.

MONTERO, P.; MOURA, F. Retrato de Grupo. 40 anos do Cebrap. São Paulo: Cosac \& Naif, 2009.

MOTTA, H. A. de L. Uma menina paulista. São Paulo: Totalidade Editora, 1992.

LAMAISON, P. La notion de maison: entrevista com Claude Lévi-Strauss. Terrain, Paris, n 9, pp. 34-39, 1987.

LOPES, J. B. Consumo da Arquitetura Nova. Revista Ou... Paris, v. 4, s/p. 1971.

PASSERON, J. 1990. Biographies, flux, itinéraires, trajectoires. Revue française de sociologie, Paris, v. 31, n.1, pp.3-22, 1990.

PIERSON, D. Recenseamento por quarteirões. Revista do Arquivo Municipal, São Paulo, v. LXII, pp. 173-175, 1939. 
PIERSON, D. Habitações de São Paulo: estudo comparativo. Revista do Arquivo Municipal, São Paulo, v. LXXXI, pp. 199-238,1942.

PONTES, H. Crítica de cultura no feminino. Mana, Rio de Janeiro, v. 14, nº 2, pp. 511-541, 2008.

PONTES, H. Cidades, cultura e gênero. Tempo Social, São Paulo, v. 28, nº.1, pp. 7-27, 2016.

PONTES, H. e MICELI, S. Memória e Utopia na cena teatral. Sociologia e Antropologia, v.2, n.4, pp.241-264, 2012.

SEGAWA, H. Arquiteturas no Brasil: 1900-1990. São Paulo: EDUSP, 2002.

SEGAUD, M. Antropologia do espaço: habitar, fundar, distribuir, transformar. São Paulo: Edições Sesc, 2016.

ROSATTI, C. G. Casas burguesas, arquitetos modernos: condições sociais de produção da arquitetura paulista. 2016. Tese (Doutorado em Sociologia), Faculdade de Filosofia, Letras e Ciências Humanas da Universidade de São Paulo.

ROSSET, F. La biographie à l'épreuve de l'écriture. In: KAENEL, P; MEIZOZ, J; ROSSET, F.; VALSANGIACOMO, N.; BADINOU, P. (Éds.). La vie et l'œuvre: recherches sur le biographique. Lausanne: Université de Lausanne, 2008.

SCHMITT, J. L'autobiographie comme récit de conversion. L'Atelier $d u$ Centre de recherches historiques. Paris, v.16, s/p, 2017.

SCOTT, J. Gênero: uma categoria útil de análise histórica. Revista Educação e Realidade, Porto Alegre, v.16, nº.2, pp.5-22, 1990.

VIANNA, D. Companheiros de Viagem. São Paulo: Brasiliense, 1984.

WILliAMS, R. A fração Bloomsbury. Plural, São Paulo, v.6, pp.139-168, 1999.

WOLFF, S. F. S. Jardim América: o primeiro bairro-jardim de São Paulo e sua arquitetura. São Paulo: EDUSP, FAPESP, Imprensa Oficial, 2001. 